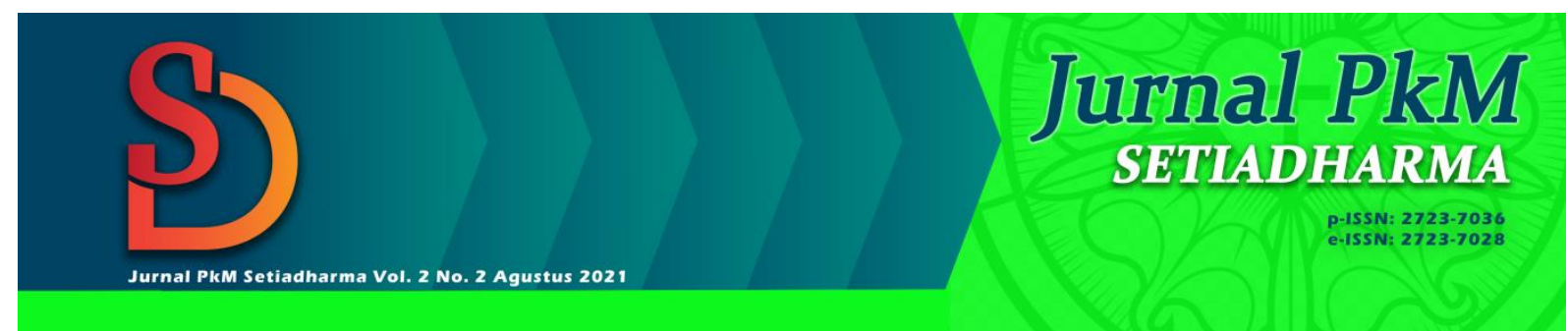

\title{
KOMSEL PEMURIDAN KREATIF PEMUDA GBI BUKIT SION
}

\author{
Naftali Untung, Rafael Oktovianus Tanonggi, John Riwu Pekuwali \\ STT Bethel Indonesia Jakarta \\ Naftaliuntung@sttbi.ac.id,rafaeltanonggi@gmail.com,johnriwu@sttbi.ac.id
}

\section{Diterima:}

16-07-2021

Direview:

06-08-2021

$13-08-2021$

Direvisi:

11-08-2021

21-08-2021

Diterbitkan:

30-08-2021

Keywords: church, pandemic covid-19, cell grup, creative

Kata Kunci: gereja; pandemi covid-19; kelompok sel; kreatif

\section{Abstract}

The outbreak of the pandemic has reduced many activities, including discipleship programs in the Christian community. Of course, GBI Bukit Sion also faces this problem. Discipleship of the younger generation in this church is no longer even running since the beginning of the pandemic. And even though it is run, there are characters from young people who get bored easily to attend events related to spirituality that must be considered. then after analyzing the needs of the church, the author's group carried out the implementation of online cell groups with sharing, mentoring, and games methods that were able to be a solution to the discipleship problem in the pandemic era.

\section{Abstrak}

Merebaknya pandemi membuat banyak kegiatan-kegiatan dikurangi, termasuk program pemuridan di komunitas Kristen. Tentunya masalah ini juga dihadapai GBI Bukit Sion. Pemuridan generasi muda di gereja ini bahkan tidak lagi berjalan sejak awal mula pandemi. Meskipun dijalankan, terdapat karakter dari pemuda yang mudah bosan untuk mengikuti acara yang berkaitan dengan spiritualitas yang harus diperhatikan. maka setelah melakukan analisis kebutuhan gereja kelompok penulis mengusung implementasi kelompok sel daring dengan metode sharing, mentoring, dan games yang mampu menjadi solusi untuk masalah pemuridan era pandemi.

\section{PENDAHULUAN}

Pandemi Covid-19 yang menyebar ke seluruh belahan dunia berdampak kepada dibatasinya kegiatan-kegiatan manusia sebagaimana mestinya sebelum kedatangan pandemi ini. Semua sektor penting mengalami dampaknya, termasuk peribadatan di gereja. Aktivitas beribadah secara tatap muka di gedung-gedung pertemuan (gereja) dengan terpaksa mesti berpindah ke ibadah tatap maya atau yang akrab dikenal virtual melalui platform online atau teknologi yang berbasis internet yang dapat mendukung pelaksanaan ibadah. ${ }^{1}$ Masalah ini tentunya tidak diingini oleh setiap manusia karena

\footnotetext{
1 Fransiskus Irwan Widjaja et al., "Menstimulasi Praktik Gereja Rumah Di Tengah Pandemi Covid-19," Kurios 6, no. 1 (2020): 127.
} 
terlalu banyak dampak buruk yang ditimbulkan. Tetapi, jika gereja ingin merefleksikan diri dalam keadaan ini, semestinya pandemi virus covid-19 dapat membawa penyadaran akan perlunya orang Kristen berpegang teguh kepada janji Yesus yang selalu melindungi orang percaya dan semakin bersungguh-sungguh datang memuji dan menyembah (ibadah) kepada-Nya. ${ }^{2}$

Orang Kristen dalam situasi pandemi covid-19 patut bersyukur karena masih dapat melaksanakan kegiatan gereja secara online dengan aman dan tetap sesuai esensinya. Sebagai contoh adalah kegiatan konseling ${ }^{3}$ dan penyerahan anak. ${ }^{4}$ Kegiatan ini bisa dilakukan dengan baik tanpa menghilangkan persekutuan antara orang percaya. Semua ini gereja lakukan dalam rangka pembangunan organisme-organisme yang ada dalam gereja untuk menuju kepada kesempuranaan seperti Kristus dalam seluruh aspek kehidupan, baik sosial, pendidikan, pekerjaan, keluarga, dan yang terpenting adalah kerohanian. Gereja memiliki tugas untuk membangun kebiasaan dan karakter hidup yang terus hidup bertumbuh, khususnya bagi pemuda-pemuda yang kelak akan meneruskan tongkat estafet gereja. Karena itu, Tuhan melalui Salomo menekankan pentingnya pemuda dibiasakan belajar firman Tuhan dan setia kepada Tuhan sampai selamanya. ${ }^{5}$

Tujuan diatas dapat dicapai dengan mengadakan pemuridan secara konsisten. Pemuridan dilakukan supaya terjadi interaksi antara pribadi-pribadi yang ada dalam kelompok pemuridan itu dan tidak monolog kepada satu orang saja yang berbicara layaknya berkhotbah. Selama ini, gereja melakukan metode kelompok sel yang dianggap efektif dalam membangun komunitas pemuridan. Model ini telah lama dilakukan yang diarahkan kepada kuatnya dasar iman orang percaya kepada Kristus, terjadi perubahan hidup yang mengarah kepada kesegambaran dengan Yesus, ${ }^{6}$ dan menjadi jemaat yang tertanam dalam gereja lokal bahkan melayani bersama. ${ }^{7}$

GBI Bukit Sion sebagai gereja yang menerapkan ibadah kelompok sel selama ini mengalami masalah tersendiri ketika berhadapan dengan pengalihan aktivitas gereja ke virtual. Dalam kuesioner yang dilakukan sebelum memulai pemuridan kepada pemuda GBI Bukit Sion, dari 20 responden, 80\% merasa pandemi membuat kehidupan rohaninya mundur. Kemunduran ini karena ibadah yang dilakukan secara online tidak dapat menyentuh kebutuhan jemaat. Selain itu, ibadah-ibadah yang dilakukan cenderung tidak menarik dan membosankan. Jemaat yang semestinya semakin mendekat kepada Allah saat menghadapi tantangan, justru merespon sebaliknya. Berhadapan dengan virus mematikan setiap hari dan mengalami hal-hal yang tidak diinginkan seperti kehilangan pekerjaan, pemotongan upah pekerja, kesulitan belajar, justru pada kenyataannya semakin mengalami kemunduran dalam kerohanian dan kehidupan ibadah selama ini.

Kemunduran kerohanian di GBI Bukit Sion bisa dilihat dari segi kuantitas yang hadir dalam ibadah live streaming (Jumlah penonton yang menonton dalam live

20nisimus Langfan, “Ibadah Online Di Masa Pandemi Covid-19: Implementasi Ibrani 12:28," Stella 1, no. 1 (2021): 15-28.

${ }^{3}$ Jelitha Saputri, "Pastoral Konseling Sebagai Strategi Penggembalaan Untuk Menuju Gereja Yang Bertumbuh," OSF Preprints (2021): 1-15.

${ }^{4}$ Admin, "Penyerahan Anak," GBI Keluarga Allah.

${ }^{5}$ Helen Farida Latif, "Pengaruh Pengajaran Dan Persekutuan Terhadap Tingkat Pertumbuhan Rohani Anak Dan Remaja," Epigraphe 1, no. 1 (2017): 119-138.

${ }^{6}$ Anggi Maringan Hasiholan, "Studi Komparatif Terhadap Pemahaman Teologi Reformed Dengan Pemahaman Teologi Pentakosta Tentang Natur Manusia,” Pneumata 1, no. 1 (2020): 54-71.

${ }^{7}$ Irwanto Berutu and Harls Evan Siahaan, "Menerapkan Kelompok Sel Virtual Di Masa Pandemi Covid-19," Sotiria 3, no. 1 (2020): 53-65. 
KOMSEL PEMURIDAN KREATIF PEMUDA GBI BUKIT SION (Naftali Untung, Rafael Oktovianus Tanonggi, John Riwu Pekuwali)

streaming ibadah dibandingkan dengan jumlah jemaat yang terdata), bisa dilihat juga dalam jumlah keterlibatan jemaat dalam kegiatan gereja yang menurun, bahkan ada yang tidak mau bergereja apabila masih online. Yang membuat penulis prihatin dari seluruh permasalahan GBI Bukit Sion adalah ibadah pemuda di GBI Bukit Sion serta pemuridan sudah tidak dilaksanakan. Hal ini menjadi fokus penulis untuk melaksanakan pemuridan secara virtual dengan memperhatikan aspek kebosanan anak muda. Karenanya perlu dikembangkan ibadah komunitas yang inspiratif, inovatif, dan kreatifMeskipun demikian, esensi koinonia tidak boleh hilang dalam pelaksanaanya yang nantinya mengarah kepada kedewasaan dalam Kristus.

Hipotesis di atas penulis paparkan karena berdasarkan temuan melalui survei yang dilakukan oleh Satuan Tugas Covid-19 didapati ada 47 persen pemuda yang mengalami kebosanan akibat dibatasinya aktivitas di luar rumah. ${ }^{9}$ Berdasarkan pemaparan masalah di atas, perlunya implementasi kelompok pemuridan virtual yang tidak membosankan namun inspiratif. Hal ini karena pemuda sangat memerlukan pembinaan, pendampingan dan pengembangan karakter dan sikap yang mengarah kepada kebenaran Firman Tuhan dan kedewasaan penuh. Peluang ini menjadi tanggung jawab bersama karena jenjang usia yang sedang dalam pencarian jadi diri dan masa depan yang hendak dicapai.

Pengabdian Kepada Masyarakat (PkM) yang dilakukan di Youth GBI Bukit Sion adalah dengan pelaksanaan kelompok sel secara virtual melalui zoom meeting dengan metode sharing, games, dan mentoring. Selain itu, perlu memperhatikan bagaimana perasaan mereka dan apa yang mereka dapatkan serta bagaimana pertumbuhan rohani mereka saat mengikuti komsel virtual bersama dengan tim Pengabdian kepada Masyarakat Prodi Teologi S1 STT Bethel Indonesia, Jakarta.

\section{METODE PELAKSANAAN}

Langkah awal yang dilakukan sebelum melaksanakan ibadah kelompok sel di pemuda GBI Bukit Sion adalah pembagian kelompok yang dilakukan dosen pengajar mata kuliah Pengabdian Masyarakat Gereja membagi mahasiswa berjumlah 58 orang ke dalam 12 kelompok (1A, 1B, 2A, 2B, 3A, 3B, 4A, 4B, 5A, 5B, 6A, 6B). Tim Pengabdian Masyarakat Gereja Kelompok 6A melakukan penetapan gereja yang akan dilayani (GBI Bukit Sion, Tomok, Kec. Simanindo, Kab. Samosir, Sumatera Utara, disetujui oleh gembala setempat Pdt. Kasdun Rumahorbo, dan pembina Sdri. Ribka Rumahorbo), selanjutnya membuat surat pengantar tugas pelayanan dari STT Bethel Indonesia, Jakarta. Setelah mendapatkan persetujuan dari pihak gereja, tim PkM melakukan observasi dan analisis kebutuhan ibadah pemuda di GBI Bukit Sion. Setelah mendapatkan kebutuhan dari lapangan, selanjutnya tahap sosialisasi dari tim PkM kepada para pemuda di GBI Bukit Sion. Sesudah tahapan di atas dilakukan oleh tim, maka kegiatan kelompok sel virtual yang mengimplementasikan metode sharing mentoring, dan games dilaksanakan selama 17 pertemuan dari 6 Maret - 3 Juli 2021.

\footnotetext{
8 Hasahatan Hutahaean and Berton Bostang Hamonangan Silaban, "Model Pembinaan Remaja Di Era Pandemik Dengan PA BGA," Jurnal PKM Setiadharma 1, no. 3 (2020): 53-58.

${ }^{9}$ Ayunda Pininta Kasih, "47 Persen Anak Indonesia Bosan Di Rumah, Akademisi IPB Beri Saran,” 13 November.
} 
Tabel 1. Observasi Kebutuhan

\begin{tabular}{|c|c|c|c|c|c|c|}
\hline Kategori & $\begin{array}{c}\text { Klarifi } \\
\text { kasi } \\
\text { usia }\end{array}$ & Ciri-ciri & Kebutuhan & $\begin{array}{c}\text { Dasar } \\
\text { Alkitab }\end{array}$ & \begin{tabular}{|c|} 
Metode \\
pendekata \\
$\mathbf{n}$ \\
\end{tabular} & $\begin{array}{c}\text { Keteran } \\
\text { gan }\end{array}$ \\
\hline \multirow{4}{*}{$\begin{array}{r}\text { Pemuda } \\
\text { Remaja }\end{array}$} & \multirow{4}{*}{$\begin{array}{l}12-27 \\
\text { tahun }\end{array}$} & $\begin{array}{c}\text { Telah menginjak } \\
\text { sekolah } \\
\text { menengah } \\
\text { pertama (SMP) }\end{array}$ & $\begin{array}{c}\text { Cara } \\
\text { mengetahui }\end{array}$ & Ef. 1:11 & Diskusi & \multirow{4}{*}{$\begin{array}{l}\text { Dilakuk } \\
\text { an } \\
\text { melalui } \\
\text { zoom } \\
\text { meeting }\end{array}$} \\
\hline & & $\begin{array}{c}\text { Sebagian telah } \\
\text { bekerja }\end{array}$ & Tujuan hidup & Kol. 1:16 & $\begin{array}{l}\text { Tanya } \\
\text { jawab }\end{array}$ & \\
\hline & & $\begin{array}{c}\text { Sebagian dalam } \\
\text { perkuliahan }\end{array}$ & \multirow{2}{*}{$\begin{array}{c}\text { Bagaimana } \\
\text { mencapai } \\
\text { cita-cita dan } \\
\text { mengetahui }\end{array}$} & \multirow{2}{*}{ Yes. 44 :2a } & Games & \\
\hline & & $\begin{array}{c}\text { Tujuan Tuhan } \\
\text { dalam kehidupan }\end{array}$ & & & $\begin{array}{c}\text { Diskusi } \\
\text { kelompok }\end{array}$ & \\
\hline
\end{tabular}

Penulis membuat kurikulum dengan penyampaian yang berbeda-beda, seperti tabel di bawah:

Tabel 2. Materi Pembahasan

\begin{tabular}{|c|c|c|}
\hline PERTEMUAN & MATERI PEMBINAAN & TANGGAL \\
\hline Pertemuan 1 & "Semuanya Diawali Dengan Allah" & 6 Maret 2021 \\
\hline Pertemuan 2 & "Anda Ada Bukan Karena Kebetulan" & 13 Maret 2021 \\
\hline Pertemuan 3 & "Diciptakan Untuk Kekekalan" & 20 Maret 2021 \\
\hline Pertemuan 4 & "Direncanakan Bagi Kesenangan Allah" & 03-Apr-21 \\
\hline Pertemuan 5 & "Menjadi Sahabat Karib Allah & $10-A p r-21$ \\
\hline Pertemuan 6 & "Diciptakan Untuk Menjadi Serupa Dengan & Kristus" \\
\hline Pertemuan 7 & "Bagaimana Kita Bertumbuh" & 24-Apr-21 \\
\hline Pertemuan 8 & "Mengalahkan Pencobaan" & 1 Mei 2021 \\
\hline Pertemuan 9 & "Dibentuk Untuk Melayani Allah" & 8 Mei 2021 \\
\hline Pertemuan 10 & "Menggunakan Apa Yang Telah Allah Berikan & 15 Mei 2021 \\
\hline Pertemuan 11 & Kepada Anda" & 22 Mei 2021 \\
\hline Pertemuan 12 & "Menjadi Seorang Kristen Kelas Dunia" & 29 Mei 2021 \\
\hline Pertemuan 13 & Games & 5 Juni 2021 \\
\hline Pertemuan 14 & "Membagikan Pesan Kehidupan Anda" & 12 Juni 2021 \\
\hline Pertemuan 15 & Doa Untuk Bangsa Dan Negara & 19 Juni 2021 \\
\hline Pertemuan 16 & How To Be Sucses & 26 Juni 2021 \\
\hline Pertemuan 17 & Perpisahan & 3 Juli 2021 \\
\hline
\end{tabular}




\section{HASIL DAN PEMBAHASAN}

Komunitas religius terpanggil untuk berkontribusi bersama pada setiap konteks dan zamannya. ${ }^{10}$ Orang Kristen yang ingin dalam hidupnya mengalami pertumbuhan kepada kesempurnaan Kristus mesti terhisap dalam komunitas sel. ${ }^{11}$ Sejalan dengan ini, Wagner menjelaskan syarat untuk gereja bahwa jikalau setiap anggota gereja aktif dalam suatu pelayanan, maka diperlukan komunitas yang mewadai setiap orang percaya, dan itu adalah kelompok sel. Jika ini diterapkan dengan konsisten, maka dipastikan gereja tersebut akan mengalami pertumbuhan ${ }^{12}$ Hal ini dibuktikan oleh Wesley pelayan Tuhan yang bergerak aktif dalam pelayanan penginjilan dan pemuridan, berhasil mengembangkan sampai sepuluh ribu kelompok sel. Atas keberhasilannya itu, Hegre menjelaskan bahwa keberhasilan pelayanan Wesley adalah karena terbangunya habit hidup dalam gereja yang berkomunitas kecil yang terdiri dari 12 orang. ${ }^{13}$ Model pemuridan dengan jumlah 12 orang memudahkan untuk setiap anggota dalam berdiskusi dan saling menguatkan satu dengan yang lain. Penulis memandang bahwa metode ini masih amat relevan untuk diterapkan dalam pemuridan-pemuridan pada saat ini.

Komsel pada dasarnya bukan aktivitas baru dalam gereja. Termasuk kegiatan yang dilaksanakan melalui media online. Sebab komsel online adalah modifikasi dan penyesuaian gereja di masa pandemi Covid-19. Persekutuan komunitas sudah dimulai sejak masa PL tepatnya ketika Allah membentuk bangsa Israel yang baru dibebaskan dari Mesir dengan kelompok-kelompok kecil.Ini memungkinkan setiap orang menerima perhatian yang lebih baik (Bil. 2, 13; Yos. 4). ${ }^{14}$ Sedangkan dalam PB, Yesus membuat pola persekutuan orang percaya dengan memilih 12 murid dan kehiduan jemaat mula-mula yang bertekun dan bersekutu dalam pertemuan tiap-tiap hari (Kis. 2:46-47). ${ }^{15}$

Secara etimologis, ibadah adalah ekspresi, bentuk sikap dan tindakan secara fisik yang tunduk dan menyembah Allah sebagai bentuk rasa hormat, ketidakberdayaan, menyembah, melayani, menghamba, dan bentuk pengharapan manusia kepada Tuhan ${ }^{16}$ Tetapi jika menelisik Firman Tuhan dalam Roma 12:1 dapat dipahami bahwa ibadah sejati ialah saat orang percaya mempersembahkan tubuh yang berarti hidup bersih, tidak bernoda, dan kudus bagi Allah. Harrison mengemukakan bahwa mempersembahkan tubuh adalah upaya menghadirkan Allah dalam kehidupan manusia. Harisson memberikan hukum otomatis antara mempersembahkan tubuh dengan kehidupan yang keluar dari kebiasaan dosa. Jika seorang Kristen secara bersungguhsungguh menyerahkan tubuhnya untuk melayani dan melakukan kebenaran Firman Tuhan, maka orang percaya pasti akan meninggalkan kebiasaan buruknya tanpa merasa menyesal. Lebih lanjut dia menjelaskan bahwa Firman Tuhan yang Paulus sampaikan

10 Tony Salurante et al., "Tanggung Jawab Menjalankan Protokol Kesehatan Di Tengah Pandemi Covid-19 Ditinjau Dari Perspektif Etika Kristen,” Visio Dei: Jurnal Teologi Kristen 3, no. 1 (2021): 63-83.

11Daniel Sutoyo, "Komunitas Kecil Sebagai Tempat Pembelajaran Gaya Hidup Kristen," Antusias 2, no. 2 (2012): 1-22.

${ }^{12}$ C. Peter Wagner, Pertumbuhan Gereja (Malang: Gandum Mas, 1989), 67.

${ }^{13}$ Obaja Tanto Setiawan, Kelompok Prinsip 12 (Solo: Departemen Media GBI Keluarga Allah, 2000), 14.

14Steve Barker et al., Pemimpin Kelompok Kecil (Jakarta: PERKANTAS, 1986), 16.

15 Amos Hosea, "Fenomena Kelompok Sel (Cell Group) Dalam Gereja Lokal," Diegesis: Jurnal Teologi 3, no. 2 (2018): 1-13.

${ }^{16}$ Alexander Stefanus Lukuhay, "Analisis Teologi Mengenai Beribadah Di Rumah Di Tengah Pandemi Covid-19 Di Indonesia,” Visio Dei 2, no. 1 (2020): 43-61. 
tidak hanya sampai pada mempersembahkan tubuh, namun juga kepada sifat persembahan itu sendiri yaitu, kudus dan berkenan kepada Allah. ${ }^{17}$

Suatu kegiatan PkM yang baik dan berdampak dapat terlihat dari hasil yang diperoleh. Hasil yang diperoleh tentunya akan objektif jika ditanyakan secara langsung kepada subjek yang dikenai kegiatan. Dalam hal ini, saat pertemuan terakhir dengan pemuda GBI Bukit Sion, tim PkM bertanya dengan menggunakan kuesioner dan wawancara secara tidak terstruktur kepada mereka terkait kepuasan pelayanan tim. Hasil yang ditemukan bahwa sebagian besar dari pemuda Bukit Sion merespons positif karena kehadiran tim Prodi S1 Teologi STTBI yang menyelamatkan ibadah pemuda yang sudah tidak berjalan selama satu tahun karena pandemi covid-19. Metode Sharing, Mentoring, serta games dapat disimpulkan terbilang sukses dan berdampak dalam memberikan pertumbuhan rohani jemaat pemuda GBI Bukit Sion.

\section{Ibadah Pemuridan Pemuda GBI Bukit Sion}

Kegiatan ibadah dilakukan dengan diawali pujian penyembahan selama 7-10 menit, setelah itu dilanjutkan dengan sharing firman Tuhan dengan topik yang telah ditulis dalam tabel di atas, firman Tuhan yang disampaikan menggunakan kurikulum yang telah disusun melalui analisis kebutuhan pemuda GBI Bukit Sion. Kurikulum disusun oleh penulis setelah melakukan wawancara dengan pemimpin gereja dan beberapa anggota pemuda. Hal utama yang diteliti adalah keadaan rohani mereka selama menghadapi pandemi covid-19 dan masalah yang ada dalam jemaat. Sudah sewajarnya memang kurikulum dibuat berbasis kebutuhan seperti yang dinyatakan oleh Parlan bahwa kurikulum ini akan meningkatkan kemandirian peserta yang mengikuti kurikulum itu. ${ }^{18}$

Setelah firman Tuhan selesai disampaikan, maka selanjutnya dilakukan kegiatan mentoring dengan melakukan breakout rooms untuk mengukur seberapa paham mereka dengan firman yang disampaikan, dalam proses mentoring ini juga biasa dipakai untuk kesaksian pribadi, hal ini tentunya bagus sebagai wadah saling menguatkan dan membagun sesama anggota komsel. Sharing ini menjadi wadah untuk setiap anggota menyampaikan masalah kehidupan mereka tanpa perlu takut dihakimi oleh yang lain. Penulis setuju dengan yang dikatakan oleh Sutoyo bahwa sharing dalam komsel membuat sesama anggota saling terbuka, mendukung, melayani, dan tumbuh bersama. ${ }^{19}$ Setelah saling sharing, mentor akan mendoakan anggotanya, dan satu anggota akan mendoakan mentornya, selanjutnya ibadah ditutup dengan doa syafaat dan doa tutup.

Liturgi ibadah tidak selalu sama setiap minggu untuk menghindari ibadah yang monoton, terkadang dilakukan games seperti adu pantun antar grup mentor, quizziz, kahoot, tebak gambar, dsb. Juga dilakukan pertemuan yang hanya berisi pujian penyembahan dan games saja. Hal ini tentunya memberikan keuntungan dari segi jumlah kehadiran yang cenderung konsisten, dan tingkat partisipasi jemaat yang tinggi.

${ }^{17}$ Dicky Dominggus, “Efektivitas Pelaksanaan Ibadah Daring Ditinjau Dari Roma 12:1-2," Sanctum Domine 10, no. 1 (2020): 35-48.

18 Parlan, "Pengembangan Kurikulum PNF Berbasis Kebutuhan Masyarakat Untuk Pembentukan Kemandirian Lulusan," Seminar Nasional Pendidikan Nonformal FKIP Universitas Bengkulu 1, no. 1 (2017): 165-171.

${ }^{19}$ Sutoyo, "Komunitas Kecil Sebagai Tempat Pembelajaran Gaya Hidup Kristen." 
KOMSEL PEMURIDAN KREATIF PEMUDA GBI BUKIT SION (Naftali Untung, Rafael Oktovianus Tanonggi, John Riwu Pekuwali)

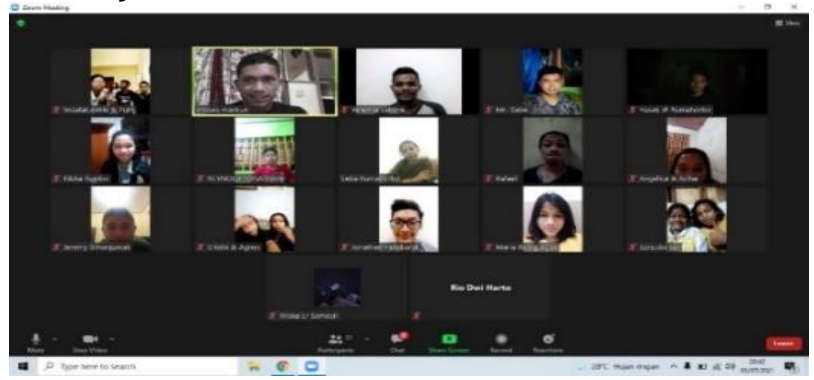

Gambar 1: Pertemuan metode Sharing tentang tujuan hidup

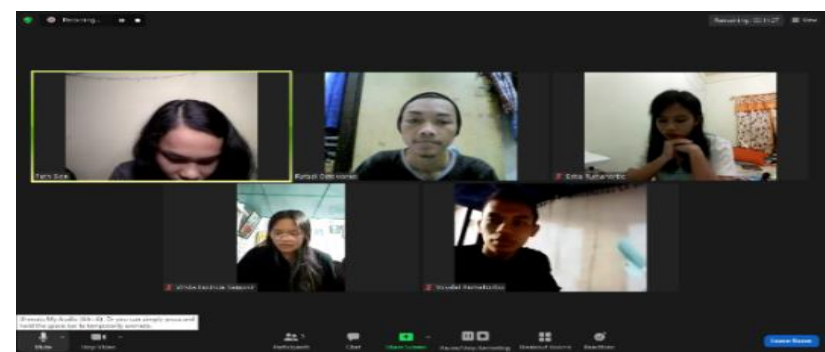

Gambar 2: Contoh Metode Mentoring memakai fitur breakout rooms zoom

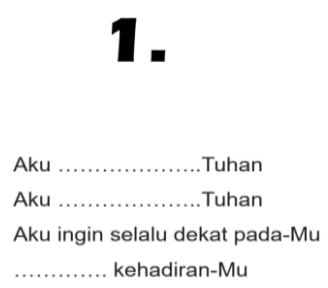

Gambar 3. contoh games tebak lirik lagu diiringi akustik gitar

Bagaimana Kepuasan temen-temen ketika kami melayani kalian?

25 jawaban

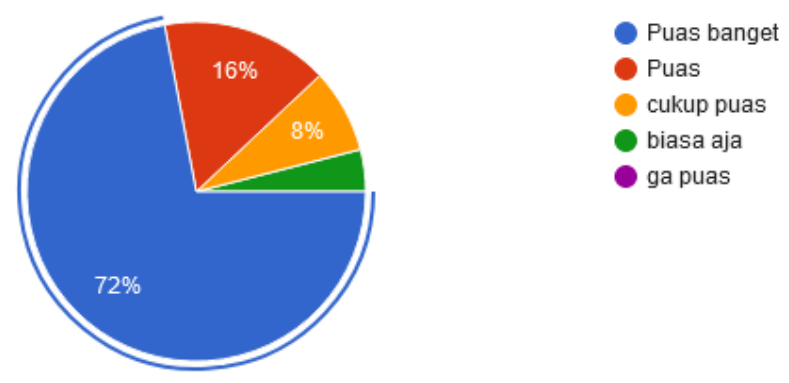

Gambar 4. Digram tingkat kepuasan pemuda GBI Bukit Sion 


\section{UCAPAN TERIMA KASIH}

Pertama-tama, tim PkM Prodi S1 Teologi mengucapkan terima kasih kepada ketua STT Bethel Indonesia, Dr. Frans Pantan yang telah memberikan kesempatan bagi kelompok untuk melaksanakan PkM ini. Tim mengucapkan terima kasih untuk dukungan moral dan morilnya serta pembekalannya sebelum proses PkM, selama proses, dan sesudah proses. Kami juga mengucapkan kepada Sdr. Anggi Maringan Hasiholan yang mengarahkan penulisan jurnal PkM dengan baik sehingga artikel ini dapat diterbitkan.

\section{KESIMPULAN}

Pada masa pandemi, komsel online yang berbasis metode sharing, mentoring, dan games ternyata digemari oleh kalangan pemuda. Kegiatan yang mengarah kepada kedewasaan iman ini telah memberi warna yang menghiasi aktivitas gerejawi orang percaya. Pandemi bisa saja menghentikan kegiatan pelayanan gereja secara langsung atau tatap muka, namun justru gereja mampu bangkit di rumah-rumah. Terkait dengan masa pandemi yang masih belum menemui titik akhir, penulis menyarankan agar gereja dan komunitas muda dapat melakukan komsel yang bervariasi dan kreatif supaya tidak ada kebosanan di kalangan anak muda untuk mengikuti kegiatan gereja. Tentunya tetap menjaga esensi (konten) yang sesuai dengan Firman Tuhan. Mungkin saja caranya (kontainer) yang disesuaikan tergantung kebutuhan dan keadann (konteks)

\section{DAFTAR PUSTAKA}

Admin. "Penyerahan Anak." GBI Keluarga Allah.

Barker, Steve, Judy Johnson, Jimmy Long, Rob Malone, and Ron Nicholas. Pemimpin Kelompok Kecil. Jakarta: PERKANTAS, 1986.

Berutu, Irwanto, and Harls Evan Siahaan. "Menerapkan Kelompok Sel Virtual Di Masa Pandemi Covid-19." Sotiria 3, no. 1 (2020): 53-65.

Dominggus, Dicky. "Efektivitas Pelaksanaan Ibadah Daring Ditinjau Dari Roma 12:1-2." Sanctum Domine 10, no. 1 (2020): 35-48.

Hasiholan, Anggi Maringan. "Studi Komparatif Terhadap Pemahaman Teologi Reformed Dengan Pemahaman Teologi Pentakosta Tentang Natur Manusia." Pneumata 1, no. 1 (2020): 54-71.

Hosea, Amos. "Fenomena Kelompok Sel (Cell Group) Dalam Gereja Lokal." Diegesis: Jurnal Teologi 3, no. 2 (2018): 1-13.

Hutahaean, Hasahatan, and Berton Bostang Hamonangan Silaban. "Model Pembinaan Remaja Di Era Pandemik Dengan PA BGA." Jurnal PKM Setiadharma 1, no. 3 (2020): 53-58.

Kasih, Ayunda Pininta. “47 Persen Anak Indonesia Bosan Di Rumah, Akademisi IPB Beri Saran." 13 November.

Langfan, Onisimus. "Ibadah Online Di Masa Pandemi Covid-19: Implementasi Ibrani 12:28." Stella 1, no. 1 (2021): 15-28.

Latif, Helen Farida. "Pengaruh Pengajaran Dan Persekutuan Terhadap Tingkat Pertumbuhan Rohani Anak Dan Remaja." Epigraphe 1, no. 1 (2017): 119-138.

Lukuhay, Alexander Stefanus. "Analisis Teologi Mengenai Beribadah Di Rumah Di Tengah Pandemi Covid-19 Di Indonesia." Visio Dei 2, no. 1 (2020): 43-61.

Parlan. "Pengembangan Kurikulum PNF Berbasis Kebutuhan Masyarakat Untuk 
KOMSEL PEMURIDAN KREATIF PEMUDA GBI BUKIT SION (Naftali Untung, Rafael Oktovianus Tanonggi, John Riwu Pekuwali)

Pembentukan Kemandirian Lulusan." Seminar Nasional Pendidikan Nonformal FKIP Universitas Bengkulu 1, no. 1 (2017): 165-171.

Salurante, Tony, Riste Silaen, Yane Keluanan, and Yosia Belo. "Tanggung Jawab Menjalankan Protokol Kesehatan Di Tengah Pandemi Covid-19 Ditinjau Dari Perspektif Etika Kristen." Visio Dei: Jurnal Teologi Kristen 3, no. 1 (2021): 63-83.

Saputri, Jelitha. "Pastoral Konseling Sebagai Strategi Penggembalaan Untuk Menuju Gereja Yang Bertumbuh." OSF Preprints (2021): 1-15.

Setiawan, Obaja Tanto. Kelompok Prinsip 12. Solo: Departemen Media GBI Keluarga Allah, 2000.

Sutoyo, Daniel. "Komunitas Kecil Sebagai Tempat Pembelajaran Gaya Hidup Kristen." Antusias 2, no. 2 (2012): 1-22.

Wagner, C. Peter. Pertumbuhan Gereja. Malang: Gandum Mas, 1989.

Widjaja, Fransiskus Irwan, Candra Gunawan Marisi, T. Mangiring Tua Togatorop, and Handreas Hartono. "Menstimulasi Praktik Gereja Rumah Di Tengah Pandemi Covid19." Kurios 6, no. 1 (2020): 127. 